\title{
Gorontalo
}

\author{
Journal of Government and Political Studies \\ Volume 4 - NO. 1 - April 2021 \\ P-ISSN: 2614-2120 E-ISSN: 2614-2104
}

\section{Membangun Karakter Bangsa Suku Bajo dalam Perspektif Identitas Etnik}

\author{
Rasid Yunus ${ }^{1}$ \\ Tonny Iskandar Mondong ${ }^{2}$ \\ ${ }^{1}$ Ilmu Hukum dan Kemasyarakatan, Fakultas Ilmu Sosial \\ ${ }^{2}$ Pendidikan Sejarah, Fakultas Ilmu Sosial \\ Universitas Negeri Gorontalo \\ J1. Jend. Sudirman No.6, Kota Tengah, Kota Gorontalo \\ rasidyunus@ung.ac.id
}

\author{
Received:18th March 2021 ; Revised: 24th March 2021; \\ Accepted: 29th March 2021
}

\begin{abstract}
Every problem that hits this nation is always closely related to the character of the nation, as happened in Pohuwato. Therefore, character problems must receive serious attention from all elements of society, government, educational institutions as well as in the implementation of socio-culture in society. During its development, national character development can be pursued with a variety of approaches, including through culture carried out by the community. The objectives of this study are: (1) The researcher wants to explore and find out in depth about the strengthening of the identity of the Bajo Tribe in Torosiaje Village, Pohuwato Regency; (2) The researcher wants to explore and know in depth the relationship between the local wisdom of the Bajo Tribe in Torosiaje Village, Pohuwato Regency with the character of the Indonesian Nation. The method used in this research is a qualitative method with a case study approach. The specific target that the researcher wants to achieve is to know in depth the values contained in the ethnic traditions of the Bajo tribe in Torosiaje Village and their correlation with the development of national character in Pohuwato, as well as Gorontalo and Indonesia in general.
\end{abstract}

Keywords: national character; Bajo Tribe

\begin{abstract}
ABSTRAK
Setiap permasalahan yang melanda bangsa ini selalu berkaitan erat dengan karakter bangsa, begitupun yang terjadi di Pohuwato. Oleh karena itu, permasalahan karakter haruslah mendapat perhatian serius dari seluruh elemen masyarakat, pemerintah, lembaga pendidikan maupun dalam pelaksanaan sosial budaya di masyarakat. Dalam perkembangannya, pembangunan karakter bangsa dapat ditempuh dengan berbagai macam pendekatan, diantaranya melalui budaya yang dilaksanakan oleh masyarakat. Tujuan penelitian ini yaitu : (1) Peneliti ingin menelusuri dan mengetahui secara mendalam tentang penguatan identitas Suku Bajo yang berada di Desa Torosiaje Kabupaten Pohuwato; (2) Peneliti ingin menelusuri dan mengetahui secara mendalam kaitan antara kearifan lokal Suku Bajo yang berada di Desa Torosiaje Kabupaten Pohuwato dengan karakter Bangsa Indonesia. Metode yang digunakan dalam penelitian ini adalah metode kualitatif dengan pendekatan studi kasus. Adapun target khusus yang ingin dicapai oleh peneliti yakni ingin mengetahui secara mendalam nilainilai yang terkandung dalam tradisi etnik Suku Bajo yang berada di Desa Torosiaje dan
\end{abstract}


korelasinya dengan pembangunan karakter bangsa di Pohuwato, serta Gorontalo dan Indonesia pada umumnya.

\section{Kata Kunci : karakter bangsa; Suku Bajo}

\section{PENDAHULUAN}

Kedaulatan, persatuan dan karakter bangsa menjadi masalah yang sering muncul dalam kehidupan berbangsa dan bernegara. Ketiga masalah tersebut memiliki keunikan sendiri-sendiri dan memerlukan kesadaran seluruh elemen bangsa Indonesia untuk mencari solusi terbaik. Jika permasalahan ini dibiarkan, maka perjalanan bangsa Indonesia akan terganggu dan tentu berimplikasi negarif pada proses pembangunan bangsa, baik proses pembangunan yang bersifat materil maupun pembangunan non materil.

Kaitannya dengan permasalahan karakter bangsa, mengacu pada pendapat Thomas Lickona, terdapat 10 tanda kehancuran suatu bangsa seperti; (1) meningkatnya kekerasan dikalangan remaja, (2) membudaya ketidakjujuran, (3) sikap fanatik terhadap kelompok, (4) rendahnya rasa hormat terhadap orang tua dan guru, (5) semakin kaburnya moral baik dan buruk, (6) penggunaan bahasa yang memburuk, (7) meningkatnya perilaku merusak diri seperti narkoba, alkohol dan sex bebas, (8) rendahnya rasa tanggungjawab sebagai pribadi dan warga negara, (9) menurunya etos kerja dan adanya saling rasa curiga, serta (10) kurangnya kepedulian diantara sesama.

Mencermati pendapat Lickona di atas, nampaknya masalah tersebut sedang terjadi di Indonesia bahkan di Pohuwato. Berbicara permasalahan karakter bangsa saat ini seluruh daerah di Indonesia mengalami masalah yang sama, walaupun level masalahnya berbeda tergantung ciri khas daerah masingmasing. Hanya saja masalah karakter tidak bisa diabaikan, karena masalah ini berkaitan langsung dengan pondasi kehidupan berbangsa dan bernegara.

Di Pohuwato masalah karakter bangsa masih sering terjadi, diantaranya perkelahian antar warga, baik melibatkan warga sesama suku maupun warga yang berbeda suka. Pada momen-momen tertentu biasanya gesekan antar suku sering terjadi, seperti pada pertandingan olahraga dan hajatan demokrasi. Walaupun gesekan yang terjadi masih tergolong biasa-biasa saja. Hanya saja, hal ini tidak bisa diabaikan. Karena konflik yang berskala besar biasanya terjadi akibat dari konflik kecil yang dianggap biasa, apalagi melibatkan sentimen etnik dan suku didalamnya.

Salah satu etnik yang terdapat di Pohuwato yakni etnik Bajo yang berada di Desa Torosiaje Kecamatan Popayato. Suku ini memiliki keunikan tersendiri, dimana seluruh aktifitas masyarakatnya berada di laut, baik membangun rumah untuk tempat tinggal, kegiatan ekonomi, politik, sosial-budaya dan lainlain. Selain itu, Suku Bajo menganggap bahwa laut merupakan tempat yang cocok untuk melangsungkan seluruh aktifitas produktif. Artinya, laut dan Suku Bajo merupakan satu kesatuan yang tidak bisa dipisahkan.

Berbicara tentang Suku Bajo berarti berbicara pula tentang keberadaan manusia Bajo yang memiliki ciri khas hidup di bibir pantai bahkan di atas laut. Suku ini memiliki sejarah tersendiri dalam persebaran sejarah suku manusia di Indonesia. Hanya saja dalam perkembanganya, Suku Bajo dalam konteks legalitas kependudukan selalu mengikuti dan masuk dalam kekuasaan teritori dimana mereka menetap. Oleh karena itu, tidaklah mengherankan jika Suku Bajo selalu memiliki legalitas penduduk di manapun mereka berada dan tidak terkecuali di Kabupaten Pohuwato. Itu artinya mereka adalah bagian dari warga 
Pohuwato dan berhak untuk dilindungi oleh pemerintah baik pemerintah daerah maupun pemerintah pusat.

Penelitian terkait Suku Bajo telah banyak dilakukan melihat populasinya yang tersebar di beberapa wilayah. Salah satunya dilakukan oleh Ellen Surtanegara. Hasil penelitian ini menunjukkan perubahan sosial pada masyarakat Bajo yang telah tinggal menetap yaitu terjadinya perubahan pola perilaku masyarakat, interaksi sosial, nilai yang dianut masyarakat, organisasi sosial dan susunan lembaga kemasyarakatan, serta perubahan lapisan sosial dalam masyarakat. Faktor yang mendorong suku Bajo untuk menetap di Kepulauan Wakatobi antara lain penurunan potensi sumber daya alam untuk memenuhi kebutuhan hidup, persediaan kayu untuk perahu yang semakin langka, didorong dengan adanya program pemerintah, serta adanya pengaruh kebudayaan dari masyarakat daratan. Dampak positif yang muncul akibat perubahan sosial tersebut yaitu munculnya kesadaran pendidikan, terciptanya lapangan pekerjaan baru, meningkatnya taraf hidup, dan modernisasi sistem perikanan. Sedangkan dampak negatif yang ditimbulkan yaitu semakin berkurangnya eksistensi adat istiadat, reorientasi pandangan hidup, serta mulai munculnya pola hidup konsumtif (Suryanegara, 2015).

Penelitian secara lebih khusus dilakukan Risanawati Pakaya terkait Suku Bajo di wilayah Lemito, Gorontalo. Etnis Bajo memiliki kebudayaan yang berbeda dengan etnis lain perbedaan tersebut kemudian sering di sebut sebagai identitas Etnis Bajo adapun identitas Etnis Bajo yang berada di Lemito adalah Bahasa Bajo, upacara-upacara adat seperti nyalamak laut, dibantang dilautang, kesenian, bentuk rumah dll, karna begitu pentingnya menjaga Budaya Bajo maka harus dilakukan pemertahanan, salah satu caranya adalah mensosialisasikan Budaya Bajo, sebagai masyarakat yang memiliki ikatan kekerabatan yang kuat masyarakat Bajo di desa Tanjung Luar menggunakan keluarga sebagai Agen Sosialisasi. Sosialisasi Budaya Bajo menggunakan keluarga sebagai agen sosialisasi secara alami. Adapun beberapa alasan bagi Etnis Bajo untuk mempertahankan Identitasnya antara lain adalah warisan leluhur harus di pertahankan, takut terjadinya bencana, sebagai pemertahanan identitas Etnis Bajo (Pakaya, 2019).

Dalam menjaga eksistensinya, Suku Baju mengahapi berbagai ancaman. Hal ini diungkapkan oleh Muhammad Obie dalam penelitiannya. Hasil kajiannya menunjukkan bahwa berbagai program pemerintah di pesisir Teluk Tomini, berupa penetapan kawasan konservasi, serta pemberian izin konsesi kepada swasta melalui Hak Pengusahaan Hutan (HPH), Hak Guna Usaha (HGU), dan usaha tambak telah menyebabkan hilangnya akses komunitas Suku Bajo terhadap sumber daya pesisir dan laut. Intervensi berbagai program pemerintah tersebut berimplikasi resettlement bagi komunitas Suku Bajo, sehingga menyebabkan terbelahnya komunitas Suku Bajo menjadi Bajo laut dan Bajo darat. Hilangnya akses Suku Bajo terhadap sumber daya pesisir dan laut, menyebabkan kelembagaan adat semakin melemah yang mengakibatkan memudarnya falsafah hidup selaras dengan alam, memudarnya etika konservasi, hilangnya kearifan lokal, hilangnya identitas diri, dan hancurnya modal sosial (Obie, 2016).

Dari penelitian terdahulu dapat kita analisis bahwa Suku Bajo merupakan salah satu kekayaan dan tradisi yang seharusnya dilestarikan. Dimana pada 
kenyataannya Suku Bajo yang tersebar di beberapa wilayah khususnya di Gorontalo mengghadapi ancaman terkait eksistensianya.

Dalam aktifitas kebudayaan sehari-hari, Suku Bajo yang berada di Desa Torosiaje Kabupaten Pohuwato Provinsi Gorontalo, mengikuti apa yang menjadi tradisi nenek moyang mereka. Salah satu diantaranya adalah menjadikan laut sebagai basis utama dalam melangsungkan aktifitas hidup. Akan tetapi, sebagai bagian dari sebuah bangsa apakah tradisi budaya yang dijalankan memiliki korelasi terhadap keberlangsungan hidup bangsa, atau memberi andil terhadap penguatan karakter bangsa secara umum, agar Suku Bajo memberi kontribusi positif terhadap pembangunan karakter bangsa baik karakter privat maupun karakter publik. Untuk itu, riset ini menjadi sangat penting untuk dilakukan.

\section{METODE PENELITIAN}

Penelitian ini menggunakan pendekatan kualitatif didasarkan pada dua alasan. Pertama, permasalahan yang dikaji dalam penelitian tentang pembangunan karakter bangsa Suku Bajo yang berada di Torosiaje Laut membutuhkan sejumlah data lapangan yang sifanya kontekstual. Kedua, pemilihan pendekatan ini didasarkan pada keterkaitan masalah yang dikaji dengan sejumlah data primer dari subjek penelitian yang tidak dapat dipisahkan dari latar alamiahnya, tanpa ada rekayasa serta pengaruh dari luar.

\section{HASIL DAN PEMBAHASAN}

Pada bagian ini akan disajikan hasil penelitian yang memuat data primer hasil wawancara terstruktur yang diperoleh dari lokasi penelitian. Pembahasan hasil penelitian disertai dengan analisis yang berbasis pada teori yang digunakan dalam penelitian ini. Hasil penelitian dan pembahasan difokuskan pada rumusan masalah dan sub bahasan yang mendukung hal tersebut.

Adapun hasil penelitian dan pembahasan memuat; 1) Penguatan identitas Suku Bajo yang berada di Desa Torosiaje, terdiri dari sub bahasan penguatan kelembagaan, proses pewarisan kearifan lokal dan dukungan pemerintah; 2) Kaitan antara kearifan lokal Suku Bajo di Desa Torosiaje dengan karakter bangsa Indonesia, terdiri dari sub bahasan nilai kearifan lokal Suku Bajo dan karakter Bangsa Indonesia.

\subsection{Penguatan Kelembagaan}

Dalam penguatan identitas Suku Bajo, peran kelembagaan sangat penting. Kelembagaan yang dimaksud adalah lembaga adat yang berfungsi menjaga dan mewariskan kearifan lokal secara terstruktur. Terstrukur berarti setiap kegiatannya terencana dengan matang setiap saat dengan melibatkan tokoh adat, pemerintah setempat dan masyarakat. Kolaborasi unsur ini penting untuk menjamin keberlangsungan adat dan kearifan lokal.

Selain lembaga adat, kelembagaan dalam penguatan Suku Bajo memuat pula lembaga yang memiliki peran dalam pelestarian budaya, seni, lingkungan dan pendidikan dalam tatanan hidup bermasyarakat. Lembaga Swadaya Masyarakat (LSM), Paguyuban dan sanggar merupakan beberapa contoh yang bisa memberi andil terhadap penguatan identitas Suku Bajo.

Dengan demikian, jika lembaga-lembaga ini berperan dengan baik maka penguatan identitas Suku Bajo akan terpelihara sepanjang masa. Akan tetapi temuan penelitian menunjukan bahwa, beberapa kendala penyebab kurang 
maksimalnya penguatan identitas Suku Bajo yakni kurang memadainya rumah adat Suku Bajo.

Rumah adat merupakan bangunan yang memiliki makna atau simbolisasi adat dan budaya masyarakat setempat. Begitu pula untuk masyarakat Suku Bajo. Artinya, jika rumah adat belum representatif sesuai dengan standar adat, maka penguatan identitas dalam konteks bangunan/materi belumlah optimal.

Lembaga adat sebagai sistem penguatan kearifan lokal. Selain sebagai sistem, lembaga ada disebut pula sebagai pranata sosial (lembaga sosial). Adapun pranata sosial berdasarkan kebutuhan hidup manusia menurut Koentjaraningrat (1985) ialah ada pranata untuk memenuhi kebutuhan manusia dalam mengatur kehidupan berkelompok secara besar-besaran atau kehidupan bernegara maupun dalam skala kecil yakni penguatan budaya seperti pemerintahan, demokrasi, kehakiman, kepartaian, kepolisian, ketentaraan dan kebudayaan termasuk kearifan lokal. Walaupun di Torosiaje rumah adat sebagai bentuk simbolisasi budaya Suku Bajo belum representatif, tetapi untuk mempertahankan kearifan lokal Suku Bajo, tetap dilaksanakan kegiatan berkebudayaan yang bertujuan untuk mempertahankan identitas kearifan lokal.

Rencana pemerintah Kabupaten Pohuwato berencana menyambungkan jalan ke laut yakni ke Desa Torosiaje, supaya memudahkan akses jalan baik masyarakat Desa Torosiaje sebagai Suku Bajo, maupun para wisatawan yang datang menikmati keindahan budaya. Tetapi hal ini mendapatkan penolakan dari aparat Desa Torosiaje maupun masyarakat Suku Bajo yang tinggal di Desa Torosiaje, respon aparat desa dan masyarakat Desa Torosiaje terhadap pembangunan jalan tembus ke Desa Torosiaje, merupakan ekspresi kolektif sensifitas kebudayaan. Ekspresi penguatan identitas Suku Bajo.

Penguatan identitas Suku Bajo nampak pula pada konsistensi mereka dalam menjaga keunikan sebagai Suku pelaut yang lengkap dengan ciri khas peralatan perahunya. Penggunaan dayung dan layar sebagai alat utama mengemudikan perahu, meskipun peralatan modern seperti penggunaan motor temple sudah banyak digunakan dalam kehidupan aktifitas melaut suku Bajo.

Menjaga identitas kearifan lokal sebagai manifestasi merawat kebudayaan, tak bisa dihindarkan dari tantang perkembangan zaman. Karena kondisi ini bisa menyebabkan kepunahan kearifan lokal. Bahkan jika tidak berhati-hati dalam menyikapi perkembangan zaman, maka akan menyebabkan kehilangan kearifan lokal sebagai identitas suku bangsa.

Bagi suku Bajo, melaut bukan hanya berkaitan dengan mata pencaharian, tetapi mempertahankan tradisi dan identitas. Selain itu, penguatan identitas Suku Bajo nampak pada sistem adatnya. Walaupun asal Suku Bajo yang berada di Desa Torosiaje berasal dari Bone Sulawesi Selatan, tetapi karena kepentingan penguatan kearifan lokal mereka mengangkat tokoh adat, disebut Punggawa yang dianggap memahami adat Suku Bajo dan mampu menjaga budaya sesuai dengan konteksnya. Walaupun identitas kebudayaan Suku Bajo yang berada di Desa Torosiaje menjadi tanggung jawab seluruh masyarakatnya. Tetapi punggawa inilah yang dianggap sebagai pemimpin pelestarian adat.

Dalam Usman M, (2013) dijelaskan bahwa Suku Bajo di Desa Torosiaje diarahkan oleh dewan adat lokal yang memiliki kekuasaan mengontrol hampir semua aspek kehidupan, baik kelahiran, penyunatan, masa remaja, perkawinan hingga meninggal dunia. Begitu besar pengaruh dewan adat ini menentukan perjalanan hidup dan aktifitas masyarakat Suku Bajo. Berdasarkan temuan 
penelitian dan pembahasan tentang penguatan identitas Suku Bajo yang berada di Desa Torosiaje, dapat disimpulkan bahwa dalam hal penguatan identitas Suku Bajo masih ada yang perlu dibenahi seperti ketersedian rumah adat yang berfungsi sebagai simbolisasi budaya. Walaupun dari segi rumah adat belum memadai, namun penguatan identitas Suku Bajo tetap nampak pada aspek lain seperti konsistensi masyarakat dalam mempertahankan Desa Torosiaje yang berada di Laut, masih ada sebagian nelayan yang menggunakan perahu layar dan mengangkat punggawa sebagai pemimpin adat yang dipercaya dapat mengatur aspek kehidupan masyarakat Suku Bajo.

\subsection{Pewarisan Kearifan Lokal dan Dukungan Pemerintah}

Dalam penguatan identitas Suku Bajo, proses pewarisan mutlak diperlukan. Penguatan, pelestarian dan keberlangsungan kearifan lokal sangat tergantung pada proses pewarisannya. Jika proses pewarisan tidak berjalan maka lambat laun tradisi akan hilang, dan masyarakat Suku Bajo akan kehilangan identitas kebudayaannya. Di Desa Torosiaje proses pewarisan kearifan lokalnya nampak pada kegiatan yang dilakukan setiap saat. Bahwa pewarisan kearifan lokal nampak pada kepercayaan dalam pengobatan penyakit jika ada masyarakat yang sakit. Walaupun sebagian masyarakat sudah mulai beralih ke medis atau dokter dalam pengobatan penyakit, tetapi masih ada sebagian masyarakat yang masih menggunakan jasa dukun.

Masih adanya masyarakat yang menggunakan jasa dukun, menandakan bahwa keberadaan dukun masih terterima di masyarakat Suku Bajo yang berada di Desa Torosiaje. Itu artinya proses pewarisan kearifan lokal ini masih berlangsung, walaupun dari segi jumlah sudah mulai berkurang. Tetapi tetap masih berlaku dan sering ditemukan pada masyarakat Suku Bajo.

Keberadaan dukun di Desa Torosiaje tidak lahir begitu saja, melainkan hadir dari pola kebudayaan itu sendiri, dan terbina lewat lembaga sosial walaupun bersifat non formal. Senada dengan realitas ini Koentjaraningrat (1985) menggambarkan bahwa dalam masyarakat terdapat pranata sosial yang mengurus kebutuhan jasmaniah dari manusia, seperti pemeliharaan kecantikan, pemeliharaan kesehatan, kedokteran, dan sebagainya.

Mengacu pada pendapat Koentjaraningrat, tentang pranata sosial yang mengurus kebutuhan jasmaniah manusia, maka praktek dukun penyakit yang berada di Desa Torosiaje merupakan pemenuhan hasrat jasmaniah. Karena di dalam praktek tersebut tersirat pengobatan tradisional yang bertujuan menyehatkan jasmani si penderita penyakit. Di samping tradisi pengobatan dukun sebagai warisan kearifan lokal Suku Bajo yang berada di Desa Torosiaje, terdapat kebiasaan yang sifatnya turun temurun proses pewarisannya pun lewat kegiatan yang dilaksanakan setiap tahun. Tradisi tersebut adalah upacara tolak bala. Kegiatan tolak bala semacam permohonan kepada sang pencipta agar Desa Torosiaje terhindar dari bencana maupun penyakit. Tradisi ini bermaksud agar masyarakat Suku Bajo dalam menjalankan aktifitas selalu diberi kesehatan oleh sang pencipta. Di Torosiaje tradisi ini diberi nama upacara Masor.

Bertahannya tradisi Masoro sampai saat ini, menandakan bahwa proses pewarisan kearifan lokal Suku Bajo di Desa Torosiaje masih berkangsung. Prosesnya pun lewat upacara adat yang terlaksana setiap tahunnya. Ini menandakan bahwa proses transmisi maupun pewarisan kearifan lokal pada Suku Bajo masih terjaga. Proses transmisinya pun seperti sudah terpola melalui 
sistem lembaga sosial non formal. Berkaitan dengan hal ini Koentjaraningrat (1985) menggambarkan dalam masyarakat berkebudayaan ada lembaga sosial yang bertujuan memenuhi kebutuhan manusia untuk berhubungan dengan Tuhan atau dengan alam gaib, seperti tempat-tempat ibadah, doa, kenduri, upacara penyiaran agama, pantangan, ilmu gaib dan sebagainya.

Disamping tradisi Masoro, proses pewarisan kearifan lokal Suku Bajo khususnya kepada generasi muda yakni keberadaan organisasi paguyuban kemahasiswaan Suku Bajo merupakan wadah bagi anak-anak Bajo untuk bersilaturahim dan menjaga identitas Suku Bajo di manapun dan dalam keadaan apapun. Praktek ini mereka lakukan bukan hanya untuk kepentingan silaturahim mahasiswa Bajo, tetapi sebagai sarana untuk mewariskan kearifan lokal Suku Bajo. Sebab di manapun mereka berada, identitas Suku Bajo selalu melekat pada mereka.

Dalam proses pewarisan kearifan lokal Suku Bajo, dari sisi pemerintah sudah cukup mendukung terutama dalam penyediaan anggaran desa untuk menyukseskan kegiatan adat, tetapi sifatnya masih bantuan bersifat insidental dan belum menjadi anggaran rutin setiap tahunnya. Begitu pula dari pemerintah Kabupaten Pohuwato, sifatnya masih bantuan terutama pembenahan fasilitas wisata di Desa Torosiaje.

\subsection{Hubungan antara Kearifan Lokal Suku Bajo di Desa Torosiaje dengan Karakter Bangsa}

Setiap tradisi budaya yang tumbuh dan berkembang dalam masyarakat pasti memiliki nilai. Begitula pula tradisi kearifan lokal yang dilaksanakan oleh masyarakat Suku Bajo di Desa Torosiaje. Salah satu nilai budaya yang dianut oleh masyarakat Suku Bajo tradisi perayaan Masoro dan Dayango. Tradisi turun temurun, meskipun tidak sejalan dengan agama Islam yang dianut oleh sebagian besar suku Bajo tetapi demi rasa persatuan sesama Suku Bajo tradisi ini tetap diadakan di desa suku Bajo. Tujuan melaksanakan tradisi ini sematamata untuk melestarikan adat sebagai salah satu instrumen pemersatu masyarakat Suku Bajo yang berada di Desa Torosiaje. Hal ini merupakan perwujudan nilai kebersamaan, persatuan dan toleransi. Bila nilai-nilai budaya ini tidak terawat pada masyarakat Suku Bajo bukan tidak mungkin akan terjadi pertentangan yang mengarah pada konflik. Karena di setiap tradisi adat, jika disandingkan dengan ajaran agama Islam pasti ada yang bertentangan. Tetapi karena unsur kebersamaan yang dikedepankan, maka pertentangan itu dapat terhindarkan.

Konsistensi menjaga nilai kebersamaan, persatuan dan toleransi merupakan bentuk komitmen terhadap pelaksanaan nilai-nilai budaya yang syarat akan pesan kebaikan. Senada dengan hal ini, dalam teori orientasi nilai budaya Kluckhon (Koentjaraningrat, 2009) berpendapat ada kebudayaan yang sangat mementingkan hubungan horisontal antara manusia dengan sesamanya. Orang dalam suatu kebudayaan seperti itu akan sangat merasa tergantung kepada sesamanya. Usaha untuk memelihara hubungan baik dengan tetangganya dan sesamanya merupakan suatu hal yang dianggapnya sangat penting dalam hidup.

Jika mengacu pada teori orientasi nilai budaya Kluckhon, apa yang dipraktekkan tokoh adat dan seluruh masyarakat Suku Bajo merupakan ekspresi berkebudayaan, yang tergantung pada kebersamaan sebagai warga dan 
memelihara hubungan baik sebagai sesama manusia. Hal ini sangat penting untuk menjamin keberlansungan hidup identitas Suku Bajo di masa-masa yang akan datang.

Suku Bajo tidak bisa dilepaskan dari identitas aslinya yakni suku pelaut. Walaupun seiring perkembangan zaman ada sebagian masyarakat mulai beralih ke bidang lain seperti PNS, pedagang dan lain-lain, tetapi tetap saja identitas Suku Bajo tidak akan hilang yakni manusia yang hidup di laut. Terkait dengan pemukiman Bumi Bahari, sebagai usaha pemerintah untuk memindahkan Suku Bajo yang tinggal di atas laut ke daratan, mendapat penolakan dari masyarakat dan akhirnya kebijakan tersebut hanya bersifat opsional (Zacot, 2002). Dalam konteks ini, apa yang dilakukan oleh masyarakat yang menolak kebijakan tersebut semata-mata untuk mempertahankan identitas. Karena secara psikologis laut merupakan bagian dari jati diri dan identitas Suku Bajo yang tinggal di Desa Torosiaje.

Disamping itu, nilai-nilai kearifan lokal terlihat pada perlakuan masyarakat Suku Bajo terhadap lingkungan. Hal ini seperti yang disampaikan oleh informan pemuka adat Suku Bajo bahwa dalam menjaga mangrove ada kerja sama dengan kawasan eko sistem esensial, dengan menambah kawasan 20 hektare untuk penanaman mangrove. Dengan adanya pelestarian mangrove maka merasa aman dari hantaman badai. Pembuatan rumah mengikuti aturan pemerintah desa, membangun rumah harus melapor untuk menata rumah dan terarah. Penambahan rumah ke arah belakang arah pesisir (hasil wawancara, 2020).

Sesuai keterangan informan di atas, terkait relasi lingkungan laut dengan Suku Bajo. Sudah menjadi hal mutlak menjaga lingkungan laut dan hal ini sudah dilakukan sejak nenek moyang. Sebagai suku yang hidup di atas laut. Lautlah menjadi tempat mereka melangsungkan kehidupan, termasuk membangun rumah dan mencari nafkah. Laut sebagai sumber untuk mempertahankan kelangsungan hidup, sehingga perlakuan terhadap lingkungan laut terutama menjaga kawasan mangrove oleh menjadi kewajiban bagi seluruh masyarakat suku Bajo.

Kehatian-hatian dan perasaan tanggung jawab terhadap lingkungan dilakukan untuk menjaga keseimbangan alam. Yang pasti ini pula dilakukan untuk menjamin keselamatan Suku Bajo di masa-masa yang akan datang. Jika salah mengelola mangrove, maka kehidupan mereka tidak nyaman dari terpaan gelombang air laut. Kecintaan Suku Bajo terhadap laut sudah terbangun secara turun temurun, bahkan sudah menjadi pola kebudayaan mereka. Dalam penelitian (Utina, R, 2011) tentang "Kecerdasan Ekologis dalam Kearifan Lokal Masyarakat Suku Bajo di Desa Torosiaje Provinsi Gorontalo". Hasil penelitian menunjukkan bahwa Suku Bajo di Desa Torosiaje memiliki kecerdasan ekologis. Hal tersebut mereka tunjukan dalam tradisi (Mamalia Kadialo) antara lain : larangan membuang limbah ke laut yang menyebabkan pencemaran laut dan mengganggu biota laut. Dilarang membuang abu dapur, abu rokok, air cabe, air jahe ke laut karena dapat mematikan ubur-ubur serta dilarang membuang air cucian wajan dan alat memasak mengandung arang yang dapat menyebabkan air keruh sehingga dapat mengganggu kehidupan terumbu karang. Penjelasan hasil penelitian Utina, R, memberi penegasan bahwa Suku Bajo di Desa Torosiaje benar-benar selektif mengelola lingkungan laut demi keberlangsungan 
ekosistem laut. Tentu hal ini memberi implikasi positif terhadap keberlangsungan ekosistem laut sebagai sumber penghidupan Suku Bajo.

Potret nilai kearifan lokal yang terbina secara turun temurun pada masyarakat Suku Bajo yang tinggal di Desa Torosiaje seperti kebersamaan, toleransi, persatuan, menjalin hubungan baik dengan masyarakat desa sekitar serta cinta terhadap lingkungan laut memiliki korelasi dengan karakter kebangsaan Indonesia. Sebab nilai karakter kebangsaan Indonesia dibangun dari tradisi dan nilai kearifan lokal masing-masing daerah yang sudah terbangun ribuan tahun yang lalu. Kemudian nilai-nilai dari tradisi ini ditransmisikan menjadi karakter bangsa Indonesia sebagai sebuah negara bangsa (national state). Pembangunan karakter bangsa yang bersandar pada nilai dan tradisi kearifan lokal sangatlah penting. Sebab hal ini berkaitan dengan originalitas karakter yang memang benar-benar tumbuh dari bangsa sendiri. Jika kita lalai memperhatikan karakter kebangsaan ini, maka keterpurukan dan keterbelakangan pastilah menanti.

Pendapat senada disampaikan oleh Azis Wahab (2009) "keterburukan bangsa saat ini, adalah karena kita telah kehilangan jati diri bangsa, yang dengan itu pada masa lalu bangsa kita amat disegani dan dihormati terutama di kawasan ini. Untuk mengatasi keadaan seperti itu, yang dibutuhkan adalah upaya pemahaman baru kebangsaan, dan merajut kembali ke-Indonesiaan guna meniti jalan memahami dan memanifestasi semangat dan cita rasa kebangsaan, untuk memantapkan kembali karakter dan jati diri bangsa".

Penegasan dari Azis Wahab ini memberi arah bahwa untuk menuju bangsa yang jaya, maka konsisten pada penguatan kearifan lokal sebagai modal budaya bangsa sangatlah urgen. Selain itu, De Vos (Budimansyah dan Suryadi, 2008:77) menggambarkan bahwa karakter bangsa merupakan ciri kepribadian yang tetap khas ditemui pada penduduk negara bangsa tertentu. Tidak terkecuali kearifan lokal Suku Bajo yang berada di Desa Torosiaje.

Berdasarkan penjalasan hubungan nilai kearifan lokal Suku Bajo dengan karakter bangsa Indonesia, dapat ditarik kesimpulan bahwa karakter Suku Bajo yang tinggal di Desa Torosiaje memiliki keterkaitan dengan karakter bangsa Indonesia. Oleh karena itu, dipandang perlu untuk membangun dan menguatkan karakter Suku Bajo di Desa Torosiaje Kecamatan Popayato Kabupaten Pohuwato Provinsi Gorontalo, sebagai bagian dari karakter bangsa Indonesia.

\section{PENUTUP}

Suku Bajo adalah masyarakat yang unik, dikenal sebagai suku pengembara laut, hidup diatas perahu selama ratusan tahun turun temurun sampai saat sekarang ini, darimana asal usulnya, masih belum diketahui dengan pasti, namun keberadaannya di Indonesia khususnya maupun di belahan dunia lain, nyata adanya. Di Gorontalo, suku Bajo sudah menetap sejak awal abad 20, meskipun sudah menetap tetapi tradisi melaut masih terus dijalankan bahkan mengalami penguatan identitas etnik karena suku Bajo sadar, hanya dengan penguatan identitas etnik Bajo, maka suku ini akan bertahan. Disamping itu, ternyata karakter sebagai warga Negara dan Bangsa Indonesia juga terbangun melalui kesadaran kolektif sebagai masyarakat suku Bajo yang secara defakto dan dejure sudah menetap sebawai warga Negara Indonesia. 


\section{DAFTAR PUSTAKA}

Budimansyah, D dan Suryadi, K. (2008). PKn dan Masyarakat Multikultural. Bandung: Sekolah Pascasarjana Program Pendidikan Kewarganegaraan Universitas Pendidikan Indonesia.

Creswell, W.J. (2010). Reseach Design Qualitative and Quantitative Approach. Penerjemah Achmad Fawaid. Yogyakarta: Pustaka Pelajar.

Koentjaraningrat. (2009). Sejarah Teori Antropologi I. Jakarta: UI Press.

Gramedia.

(1985). Kebudayaan Mentalitas dan Pembangunan. Jakarta:

Lickona, T. (1992). Educating For Character How Our Schools Can Teach Respect and Responsibility. New York-Toronto-London-Sydney-Auckland: Bantam Books.

Lincoln, S.Y dan Denzin, K.N. (2009). Hanbook of Qualitative Research. Yogyakarta: Pustaka Pelajar.

Miles, M dan Huberman, A.M. (2007). Analisis Data Kualitatif: Buku Sumber Tentang Metode-Metode Baru. Jakarta: Universitas Indonesia Press.

Moleong, L.J. (2006). Metode Penelitian Kualitatif. Bandung: PT Remaja Rosdakarya.

Nasution, S. (2002). Metode Penelitian Naturalistik Kualitatif. Bandung: Tarsito.

Nazir, M. (2011). Metode Penelitian. Jakarta: Gahlia Indonesia.

Pakaya, R. (2019). Suku Bajo di Lemito Dalam Persfektif Sejarah Sosial. Skripsi, 1(231413047).

Pemerintah Republik Indonesia. (2010). Desain Induk Pembangunan Karakter Bangsa Tahun 2010-2025.

Rahardjo K. Toto (2006). Bung Karno, Islam, Pancasila dan NKRI. Jakarta: Komunitas Nasional Religius Indonesia.

Sapriya. (2008). "Perspektif Pemikiran Pakar tentang Pendidikan Kewarganegaraan dalam Pembangunan Karakter Bangsa (Sebuah Kajian Konseptual-Filosofis dalam Pendidikan Kewarganegaraan dalam Konteks Pendidikan IPS". Jurnal Acta Civicus. "Vol" 1, (2).

Satori, D dan Komariah, A. (2011). Metodologi Penelitian Kualitatif. Bandung: Alfabeta.

Suryanegara, E., \& Nahib, I. (2015). Perubahan Sosial Pada Kehidupan Suku Bajo: Studi Kasus Di Kepulauan Wakatobi, Sulawesi Tenggara. Majalah Ilmiah Globe, 17(1), 67-78.

Wahab A. Azis (2009). Memantapkan Kembali Jati Diri Bangsa dalam Rangka Penguatan Dasar-Dasar Pendidikan Kewarganegaraan Indonesia. Makalah disampaikan pada Seminar Pendidikan Kewarganegaraan. UPI Bandung, tanggal 12 Desember 2009.

Yunus, Rasid. (2013). Transformasi Nilai-Nilai Budaya Lokal sebagai Upaya Pembangunan Karakter Bangsa (Studi Kasus Budaya Huyula di Kota Gorontalo). Jurnal Penelitian Pendidikan, Vol. 14 No.1, April 2013: LPPM UPI Bandung.

Zacot, R. Francois. (2002). Orang Bajo Suku Pengembara Laut. Jakarta Selatan: Kepustakaan Populer Gramedia (KPG). 